\title{
Soil physical properties, nutrients, and crop yield with two-year tillage rotations under a winter wheat-summer maize double cropping system
}

\author{
Baozhong Yin ${ }^{1,2,3 \dagger}$, Pan Liu ${ }^{4 \dagger}$, Yongwei Cui ${ }^{5}$, Zhaohui $\mathrm{Hu}^{6}$, Xiangling Li ${ }^{7}$, \\ Zhihua Pan ${ }^{1 *}$, Wenchao Zhen ${ }^{3,4,8^{*}}$ \\ (1. College of Resources and Environment Sciences, China Agricultural University, Beijing 100193, China; \\ 2. College of Plant Protection, Hebei Agricultural University, Baoding 071001, Hebei, China; \\ 3. State Key Laboratory of North China Crop Improvement and Regulation, Baoding 071001, Hebei, China; \\ 4. College of Agronomy, Hebei Agricultural University, Baoding 071001, Hebei, China; \\ 5. Academy of Agricultural Planning and Engineering, Ministry of Agriculture and Rural Affairs, Beijing 100125, China; \\ 6. College of Life Science, Hebei Agricultural University, Baoding 071001, Hebei, China; \\ 7. Hebei Normal University of Science and Technology, Qinhuangdao 066000, Hebei, China; \\ 8. Key Laboratory of Crop Growth Regulation of Hebei Province, Baoding 071001, Hebei, China)
}

\begin{abstract}
Winter wheat and summer maize were planted from 2015-2017 to study the effects of different rotational tillage patterns on soil physicochemical properties, crop yield, water content, and fertilizer utilization. The tillage treatments were designed as wheat subsoiling-maize no tillage (WS-MN), wheat rotary tillage-maize subsoiling (WR-MS), wheat subsoiling-maize subsoiling (WS-MS), and conventional wheat rotary tillage-maize no tillage (WR-MN) as a control. Among the four treatments, WS-MN and WR-MS were single-season subsoiling treatments, and WS-MS was a two-season subsoiling treatment. The average soil bulk density decreased by $7.6 \%$ in the single- and double-season subsoiling groups compared to the WR-MN group, and the total porosity and noncapillary porosity increased by $10.7 \%$ and $12.2 \%$, respectively. Single- or double-season subsoiling treatment was not conducive to water storage in the $0-20 \mathrm{~cm}$ soil layer but increased the water content of the $20-140 \mathrm{~cm}$ soil layer, and the average soil water content of the $0-140 \mathrm{~cm}$ layer was increased by $11.6 \%$ in the two-growing season treatment groups compared with the WR-MN group. In WS-MS and WS-MN groups compared with the WR-MN group, the soil ammonium nitrogen content was increased by an average of $18.6 \%$ in $0-20 \mathrm{~cm}$ soil and $16.8 \%$ in $20-100 \mathrm{~cm}$ soil; soil nitrate-nitrogen content was decreased by $13.5 \%$ in $0-100 \mathrm{~cm}$ soil; total organic carbon and microbial carbon contents in the $15-30 \mathrm{~cm}$ soil were increased by $18.1 \%$ and $12.7 \%$, respectively; and soil urease, catalase, and alkaline phosphatase activities were increased by $46.1 \%, 15.2 \%$, and $23.1 \%$, respectively. Annual crop yield and water use efficiency increased by $8.9 \%$ and $15.0 \%$, respectively, in both the single- and double-season subsoiling treatment groups. This study demonstrated the advantages of subsoiling tillage and suggested that it is suitable for crop cultivation in the Haihe Plain, China. Keywords: tillage rotations, wheat-maize double cropping, soil properties, utilization of water and fertilizer, crop yield DOI: $10.25165 /$ j.ijabe.20221501.6855
\end{abstract}

Citation: Yin B Z, Liu P, Cui Y W, Hu Z H, Li X L, Pan Z H, et al. Soil physical properties, nutrients, and crop yield with two-year tillage rotations under a winter wheat-summer maize double cropping system. Int J Agric \& Biol Eng, 2022; 15(1): $172-181$.

\section{Introduction}

Water, fertilizer, air, heat, and microbes are the main determinants of the soil ecological environment ${ }^{[1,2]}$, all of which

\section{Received date: 2021-06-22 Accepted date: 2021-11-24}

Biographies: Baozhong Yin, PhD, Associate Professor, research interest: physiological ecology of crop stress resistance, Email: yinbaozhong@ hebau.edu.cn; Pan Liu, PhD, research interest: crop cultivation physiology, Email: 523608222@qq.com; Yongwei Cui, PhD, research interest: agricultural and rural regional development and informatization, Email: cuiyongwei@ 126.com; Zhaohui Hu, PhD, Associate Professor, research interest: plant physiology, Email: smyhuzh@hebau.edu.cn; Xiangling Li, PhD, research interest: crop cultivation physiology, Email: ncqyfz2008@126.com.

$\uparrow$ Baozhong Yin and Pan Liu contributed equally to this study.

*Corresponding author: Zhihua Pan, $\mathrm{PhD}$, Professor, research interest: agrometeorology and agroecology. College of Resources and Environment, China Agricultural University, Beijing 100193, China. Tel: +86-10-62733839, Email: Panzhihua@cau.edu.cn; Wenchao Zhen, PhD, Professor, research interest: Agricultural water saving ecology. College of Agronomy, Hebei Agricultural University, Baoding 071001, Hebei, China. Tel: +86-3127528996, Email: wenchao@hebau.edu.cn. will significantly affect the root function, the quality, and the yield of crops $^{[3,4]}$. Tillage changes soil properties, including soil porosity, aggregate structure, particle-water-air ratio, and soil water-heat characteristics, It is an important way to regulate soil ecological environment ${ }^{[5]}$. Therefore, for a long time, it has been considered as an important part of crop high-yield and high-efficiency cultivation system to optimize farming measures, change the ecological environment of crop root growth and promote crop growth and development ${ }^{[6,7]}$.

However, not every variant of tillage type is suitable for every situation, especially in areas where a single tillage method is continuously used, several major constraints are associated with climate and soil type, high levels of crop residue, and mixed cropping systems. For example, as a typical conservation tillage method, no-tillage plays a pivotal role in the achievement of ecological agricultural production ${ }^{[8,9]}$. Nevertheless, many studies have found that long-term no-tillage also has some disadvantages, especially long-term no-tillage (NT) in the same field will reduce the soil temperature ${ }^{[10]}$, improve the compactness, and increase $\mathrm{N}_{2} \mathrm{O}$ emissions ${ }^{[11,12]}$. The results of studies on reduced tillage are 
similar $^{[13]}$. Although the crop yield can be increased in a short period of reduced tillage, long-term shallow rotation causes the plough pan to move up, reduces soil permeability, and ultimately restricts crop root system growth ${ }^{[14]}$. Therefore, developing a soil tillage model suitable for crop planting systems and ecological conditions is essential for long-term single tillage ${ }^{[15]}$.

Subsoiling tillage (ST) can be used to mechanically disrupt hardpans to promote better water infiltration ${ }^{[16,17]}$, increase soil porosity ${ }^{[18]}$, optimize root space-time distribution ${ }^{[19]}$, and ultimately improve crop yield ${ }^{[20,21]}$. Therefore, the combination of soil ST and NT has positive significance to improve soil physical and chemical properties and promote crop growth. Studies have shown that by alternating the use of NT and ST, the water content of the $0-20 \mathrm{~cm}$ soil layer can be increased by $8 \%$ in the maize growing season and by $6 \%$ in the intermittent season ${ }^{[22]}$. In addition, alternating the use of NT and ST increases the yield of red peas by $3000 \mathrm{~kg} / \mathrm{hm}^{2}$ and barley by $600 \mathrm{~kg} / \mathrm{hm}^{2}$ in areas with poor soil fertility ${ }^{[23]}$. RT, ST, and deep ploughing tillage can be used alternately to effectively solve the problems with soil porosity, especially capillary porosity reduction and soil compaction caused by long-term NT in plots with low soil bulk density ${ }^{[14]}$. Many studies have shown that in addition to the ecological significance of conservation tillage, attention should be paid to the beneficial effects of rational rotation on optimizing soil physical and chemical properties and improving water and fertilizer use efficiency ${ }^{[5,14,24]}$.

The Haihe Plain is located in the northern part of the North China Plain ${ }^{[25]}$. It is an important grain-producing area in China, and the winter wheat-summer maize double cropping system as well as returning the whole crop straw to the field is the main planting method in this region. The winter wheat is prepared by rotary tillage (RT) with a $15 \mathrm{~cm}$ soil depth, and the summer maize is no-tillage sowing $(\mathrm{NT})^{[17,26]}$. Although this tillage rotation system can make full use of resources such as light, heat and arable land, and may be favorable for soil physical functionality as well as agronomic and environmental functions ${ }^{[27-29]}$. However, the tillage combination is adopted in farmland year by year has very obvious effects on the raising of plough pan layer and subsoil compaction $^{[30]}$, especially coupled with the effects of returning crop straw and mechanical compaction. These changes in structural pores negatively affect water movement and root growth, temporally as well as spatially ${ }^{[31-33]}$, and ultimately affect the yield of crops. Therefore, developing a soil tillage model suitable for crop planting systems and ecological conditions is essential for long-term single tillage.

Based on the above problems, a two-year experiment on the combination of RT and ST in the wheat season and NT and ST in the maize season was conducted, which aimed to determine the effects of different rotation tillage treatments on soil physical and chemical characteristics, water heat and respiration characteristics, yield, and water-fertilizer utilization. Finally, through the selection of the best winter wheat-summer maize annual rotation tillage measures, this study provides technical support for water saving, stress resistance, a high yield, and the efficient utilization of resources in the Haihe Plain of China.

\section{Materials and methods}

\subsection{Trial site description}

The experiment was conducted during the 2015-2016 and 2016-2017 winter wheat-summer maize growing seasons at the Dryland Farming Institute of Hebei Academy of Agriculture and Forestry Sciences $\left(38^{\circ} 01^{\prime} \mathrm{N}, 115^{\circ} 32^{\prime} \mathrm{E}\right)$. The soil type of the test site was loam soil with a bulk density of $1.42 \mathrm{~g} / \mathrm{cm}^{3}$ in the $0-20 \mathrm{~cm}$ soil layer, $1.49 \mathrm{~g} / \mathrm{cm}^{3}$ in the $20-40 \mathrm{~cm}$ soil layer, $1.52 \mathrm{~g} / \mathrm{cm}^{3}$ in the $40-60 \mathrm{~cm}$ soil layer, $1.58 \mathrm{~g} / \mathrm{cm}^{3}$ in the $60-80 \mathrm{~cm}$ soil layer, $1.52 \mathrm{~g} / \mathrm{cm}^{3}$ in the $80-100 \mathrm{~cm}$ soil layer, $1.35 \mathrm{~g} / \mathrm{cm}^{3}$ in the 100 $120 \mathrm{~cm}$ soil layer, $1.60 \mathrm{~g} / \mathrm{cm}^{3}$ in the $120-140 \mathrm{~cm}$ soil layer, $1.60 \mathrm{~g} / \mathrm{cm}^{3}$ in the $140-160 \mathrm{~cm}$ soil layer, $1.45 \mathrm{~g} / \mathrm{cm}^{3}$ in the 160 $180 \mathrm{~cm}$ soil layer, and $1.52 \mathrm{~g} / \mathrm{cm}^{3}$ in the $180-200 \mathrm{~cm}$ soil layer. In the $0-20 \mathrm{~cm}$ soil layer, the alkali-hydro nitrogen, available phosphorus, available potassium, and soil organic matter contents were $66.7 \mathrm{mg} / \mathrm{kg}, 24.1 \mathrm{mg} / \mathrm{kg}, 122.4 \mathrm{mg} / \mathrm{kg}$, and $14.7 \mathrm{~g} / \mathrm{kg}$, respectively. The rainfall amount was $131.4 \mathrm{~mm}$ in the $2015-2016$ wheat season, $292.1 \mathrm{~mm}$ in the 2016 maize season; $125.4 \mathrm{~mm}$ in the 2016-2017 wheat season, and $306.6 \mathrm{~mm}$ in the 2017 maize season (Figure 1).
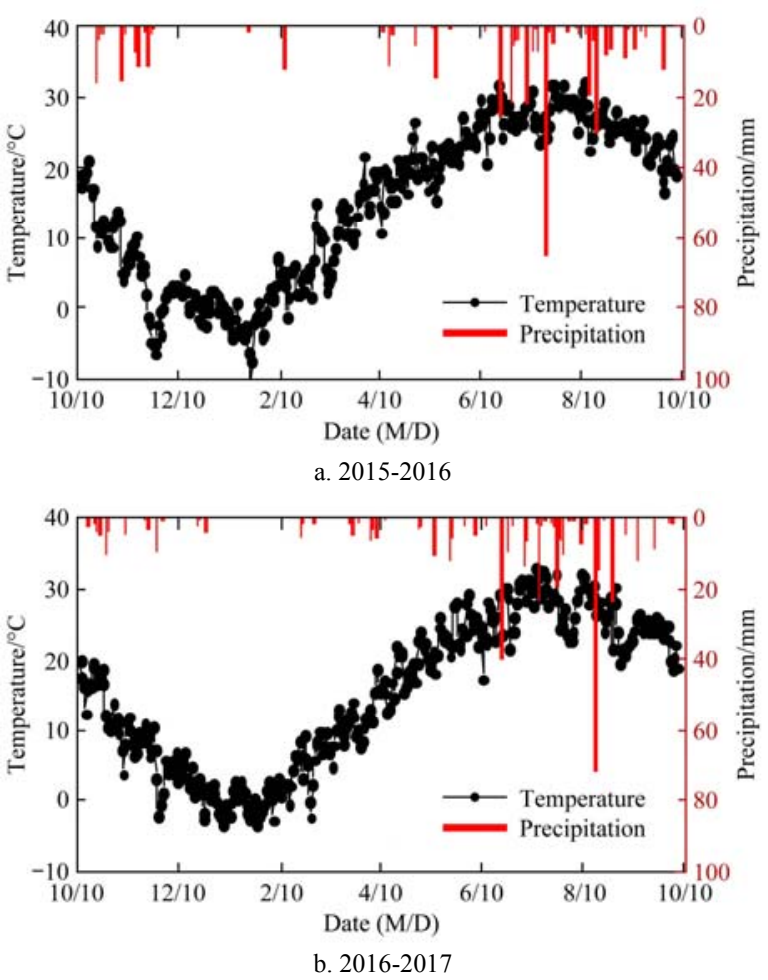

Figure 1 Precipitation and average temperature for the wheat-maize double cropping systems in 2015-2016 and 2016-2017

\subsection{Field management and experimental design}

A random block design was used with four replicates per block in this experiment; each plot was $450.0 \mathrm{~m}^{2}(10.0 \mathrm{~m}$ long $\times 45.0 \mathrm{~m}$ wide). The following four tillage systems were applied: RT in the wheat season and NT in the maize season (WR-MN) (Control), ST in the wheat season and NT in the maize season (WS-MN), RT in the wheat season and ST in the maize season (WR-MS), and ST in the wheat season and ST in the maize season (WS-MS).

RT treatment in wheat season: Maize straw crushing and returning to the field (1JQ-220 type straw returning machine) $\rightarrow$ fertilization (ZC-240 type fertilizer spinner) $\rightarrow$ Rotary tillage (1GN-180 type rotary cultivator, which was used for rotary tillage twice at a depth of $15 \mathrm{~cm}$ ) $\rightarrow$ Sowing (2BFX14 type wheat planter).

ST treatment in wheat season was designed as maize straw crushing and returning to the field (1JQ-220 type straw returning machine) $\rightarrow$ Subsoiling tillage and fertilization (2FS type subsoiling, rotary tillage and fertilization integrated machine, which can complete fertilization, subsoiling and rotary tillage simultaneously; the subsoiling depth was $30 \mathrm{~cm}$ and its subsoiling shovels interval was $60 \mathrm{~cm}$; the rotary tillage depth was $15 \mathrm{~cm}$, and this link is operated once) $\rightarrow$ Sowing (2BFX14 type wheat planter). 
NT treatment in maize season: Wheat harvest $\rightarrow$ Sowing (2BQF-5 type maize no-till precision seeder, and this machine can complete fertilization and sowing simultaneously).

ST treatment in maize season: Wheat harvest $\rightarrow$ Sowing (2BMSQFY-4 type maize Subsoiling full layer fertilization precision seeder, and the machine was integrated with subsoiling and sowing through alternating loosening and sowing processes, with a tillage depth of $25 \mathrm{~cm}$ ).

The basal fertilizer consisted of pure $\mathrm{N}\left(120 \mathrm{~kg} / \mathrm{hm}^{2}\right), \mathrm{P}_{2} \mathrm{O}_{5}$ $\left(112.5 \mathrm{~kg} / \mathrm{hm}^{2}\right)$, and $\mathrm{K}_{2} \mathrm{O}\left(112.5 \mathrm{~kg} / \mathrm{hm}^{2}\right)$, and the spring fertilizer consisted of pure $\mathrm{N}$ at $120 \mathrm{~kg} / \mathrm{hm}^{2}$ during the wheat season. In the maize season, fertilizer comprising pure $\mathrm{N}\left(225 \mathrm{~kg} / \mathrm{hm}^{2}\right), \mathrm{P}_{2} \mathrm{O}_{5}$ $\left(120 \mathrm{~kg} / \mathrm{hm}^{2}\right)$, and $\mathrm{K}_{2} \mathrm{O}\left(90 \mathrm{~kg} / \mathrm{hm}^{2}\right)$ was applied. Slow-release and quick-acting nitrogen fertilizers were provided at a 1:1 ratio. The wheat variety that was tested was 'Heng 4399,' and the basic seedling rate was $3.75 \times 10^{6}$ plants $/ \mathrm{hm}^{2}$. Winter wheat was irrigated twice in spring, and fertilizer was applied with the first irrigation. The maize variety under test was 'Zhengdan 958', and the planting density was 63000 plants $/ \mathrm{hm}^{2}$. The relevant irrigation, sowing, and harvest information are listed in Table 1.

Table 1 Sowing, harvest, irrigation dates and amounts in the wheat-maize double cropping system from 2015-2016 and 2016-2017

\begin{tabular}{|c|c|c|c|c|c|c|c|c|c|}
\hline \multirow{2}{*}{$\begin{array}{l}\text { Growing } \\
\text { season }\end{array}$} & \multicolumn{6}{|c|}{ Winter wheat } & \multicolumn{3}{|c|}{ Summer maize } \\
\hline & $\begin{array}{l}\text { Sowing date } \\
\text { (M/D) }\end{array}$ & $\begin{array}{l}\text { Irrigation date } \\
(\mathrm{M} / \mathrm{D})\end{array}$ & $\begin{array}{l}\text { Irrigation } \\
\text { amount } / \mathrm{mm}\end{array}$ & $\begin{array}{l}\text { Irrigation date } \\
(\mathrm{M} / \mathrm{D})\end{array}$ & $\begin{array}{l}\text { Irrigation } \\
\text { amount } / \mathrm{mm}\end{array}$ & $\begin{array}{l}\text { Harvest date } \\
(\mathrm{M} / \mathrm{D})\end{array}$ & $\begin{array}{l}\text { Sowing date } \\
\text { (M/D) }\end{array}$ & $\begin{array}{l}\text { Irrigation date } \\
(\mathrm{M} / \mathrm{D})\end{array}$ & $\begin{array}{l}\text { Harvest date } \\
(\mathrm{M} / \mathrm{D})\end{array}$ \\
\hline $2015-2016$ & $10 / 12$ & $04 / 01$ & 74.6 & $05 / 01$ & 75.5 & $06 / 11$ & $06 / 17$ & 52.5 & $10 / 04$ \\
\hline $2016-2017$ & $10 / 12$ & $03 / 29$ & 79.5 & $05 / 02$ & 67.5 & $06 / 12$ & $06 / 16$ & 60.5 & $10 / 05$ \\
\hline
\end{tabular}

Note: According to $90 \%$ of the field water-holding capacity of $0-80 \mathrm{~cm}$ soil, the relative water content of $0-80 \mathrm{~cm}$ soil layer after three irrigations in the wheat maize cropping season was 88\% (measured on April 2, 2016), 87.5\% (measured on May 2, 2016) and 87.2\% (measured on June 18, 2016), respectively, from 2015-2016. The relative water content of the $0-80 \mathrm{~cm}$ soil layer after three irrigations in the wheat maize growing season was $88.2 \%$ (measured on March 30,2017 ), $87.1 \%$ (measured on March 30, 2017) and 87 0\% (measured on June 17, 2017), respectively, from 2016-2017.

\subsection{Analysis of soil properties}

\subsubsection{Soil bulk density, porosity}

The $0-10 \mathrm{~cm}, 10-20 \mathrm{~cm}$, and $20-30 \mathrm{~cm}$ soil layers were sampled at the wheat seedling stage, wheat jointing stage, wheat maturity stage, maize heading stage, and maize maturity stage. Three sample points were randomly selected in each cell, and a total of 12 sample points were sampled for each process. The samples were used to determine the bulk density, total porosity, capillary porosity, and non-capillary porosity.

The main indices were total porosity $\left(P_{1}, \%\right)$, capillary porosity $\left(P_{2}, \%\right)$, and noncapillary porosity $\left(P_{3}, \%\right)$, and the corresponding calculation equations are as follows:

$$
\begin{gathered}
P_{1}=\left(1-D_{1} / D_{2}\right) \times 100 \% \\
P_{2}=(F C-\mathrm{VTM}) \times D_{1} \times 100 \% \\
P_{3}=P_{1}-P_{2}
\end{gathered}
$$

where, $D_{1}$ is the soil bulk density $\left(\mathrm{g} / \mathrm{cm}^{3}\right)$, which was determined by the cutting ring method ${ }^{[34]} ; D_{2}$ is the particle density $\left(\mathrm{g} / \mathrm{cm}^{3}\right)$, which was calculated by using the pycnometer method ${ }^{[35,36]} ; F_{C}$ is the soil field capacity, which was determined according to the field method $^{[36]}$; VTM is the soil wilting moisture content, which was measured by the pressure pot method ${ }^{[21,37]}$.

\subsubsection{Soil nutrient parameters}

After maize harvest, the $0-10 \mathrm{~cm}, 10-20 \mathrm{~cm}, 20-40 \mathrm{~cm}$, $40-60 \mathrm{~cm}, 60-80 \mathrm{~cm}, 80-100 \mathrm{~cm}$, and $100-120 \mathrm{~cm}$ soil layers were sampled to determine nitrate and ammonium nitrogen contents ${ }^{[38]}$. Soil nitrate nitrogen was extracted with $1 \mathrm{~mol} / \mathrm{L} \mathrm{KCl}$, and its content was determined by a flow analyzer (Auto Analyser 3, Germany $)^{[39]}$. Soil ammonium nitrogen content was determined by ultraviolet spectrophotometry.

\subsubsection{Soil enzyme activity}

The $0-15 \mathrm{~cm}$ and $15-30 \mathrm{~cm}$ soil layers were sampled to determine the activities of urease (URE), polyphenol oxidase (ALP), catalase (CAT), alkaline phosphatase (PPO), total soil organic carbon (SOC), soil microbial biomass carbon (SMBC), and active microbial biomass (AMB). Soil enzyme activity was determined by the indophenol colorimetry method, sodium phenyl phosphate colorimetric method, potassium permanganate titration method, and pyrogallol colorimetric method, as previously described $^{[40]}$.

Soil organic carbon (SOC) content was determined using the potassium dichromate volumetric method. The soil microbial biomass carbon (SMBC) content was determined by the chloroform fumigation- $\mathrm{K}_{2} \mathrm{SO}_{4}$ extraction method and calculated using the following equation ${ }^{[41]}$ :

$$
\mathrm{SMBC}=\mathrm{EC} / \mathrm{K}_{\mathrm{EC}}
$$

where, $\mathrm{EC}$ is the difference in carbon content between fumigated and nonfumigated soil $\mathrm{K}_{2} \mathrm{SO}_{4}$ extracts; $\mathrm{K}_{\mathrm{EC}}$ is the conversion coefficient, the value of which is 0.38 .

The number of active microorganisms in the soil was determined by mathematical analysis of the respiratory curve. Specifically, $1 \mathrm{~g}$ of fresh soil was added to $0.4 \mathrm{~mL}$ glucose medium. $\mathrm{CO}_{2}$ release was measured after $24 \mathrm{~h}$ of incubation at $20^{\circ} \mathrm{C}$. The microbial quotient was calculated as follows ${ }^{[42]}$ :

\section{Microbial quotient $=\mathrm{SMBC} / \mathrm{SOC}$}

\subsubsection{Soil temperature, water content, and respiration rate}

The daily average temperature of the $10 \mathrm{~cm}$ soil layer was monitored from wheat sowing to maize harvest. The soil respiration rate was measured every $15 \mathrm{~d}$. The water content in $2 \mathrm{~m}$ soil was measured before sowing and after harvest of wheat and maize. The soil respiration rate was measured using the dynamic closed gas chamber method with a Li-6400 instrument ${ }^{[43]}$. The soil temperature was measured using an HL20-type meteorological data acquisition device. The soil water content (volumetric water content, \%) was determined with a TRIME-PICO portable moisture-measuring instrument.

\subsubsection{Yield components and water use efficiency (WUE)}

In the harvest period, $1.0 \mathrm{~m}$ long and 11 rows wide $(1.5 \mathrm{~m})$ plots were randomly selected from each replicate of wheat, and all ears were collected and converted to ears per unit area; 20 ears from each replicate were randomly selected, the grains per ear were counted, and the grain weight and yield were calculated according to the standard moisture content of $12.5 \%$ after drying. $20 \mathrm{~m}$-long and 5 row-wide $(2.4 \mathrm{~m})$ plots were randomly selected from each replication of maize, and all ears were collected and converted to ears per unit area; 20 ears were selected in each plot, the number of grains per ear was counted, and the grain weight and yield were calculated according to the standard moisture content of $14.0 \%$ after drying. The yield of wheat and maize at maturity was measured to calculate the WUE and PFP. The following formula was used ${ }^{[44]}$ :

$$
\text { WUE }=Y / E T
$$


where, WUE is the water use efficiency, $\mathrm{kg} /\left(\mathrm{hm}^{2} \cdot \mathrm{mm}\right)$; ET is evapotranspiration per unit area, $\mathrm{mm} ; Y$ is the yield, $\mathrm{kg} / \mathrm{hm}^{2}$.

2.3.4 Total nitrogen accumulation (TNA) and partial fertilizer productivity (PFP)

The total nitrogen content (TNC) in the above-ground part of the plant was determined after wheat and maize harvesting using a Kjeldahl analyzer, and the TNC of the plants was calculated as follows $^{[38]}$ :

$$
\mathrm{TNC}=\mathrm{DWP} \times \mathrm{PDP} \times \mathrm{NCP}
$$

where, TNC is total nitrogen accumulation, $\mathrm{kg} / \mathrm{hm}^{2}$; DWP is the dry weight per plant; NCP is the nitrogen content per plant at harvest time, \%; PDP is the plant density per plot.

The partial productivity of fertilizer was calculated as follows:

$$
\mathrm{PFP}=Y / F
$$

where, PFP is the partial productivity of fertilizer, $\mathrm{kg} / \mathrm{kg} ; \mathrm{F}$ is the input of pure nutrients of fertilizer $\left(\mathrm{N}, \mathrm{P}_{2} \mathrm{O}_{5}, \mathrm{~K}_{2} \mathrm{O}\right), \mathrm{kg} / \mathrm{hm}^{2}$.

\subsection{Data analysis}

All data are presented as the mean $\pm \mathrm{SD}$ (standard deviation). Analysis of variance (ANOVA) was performed using the SPSS
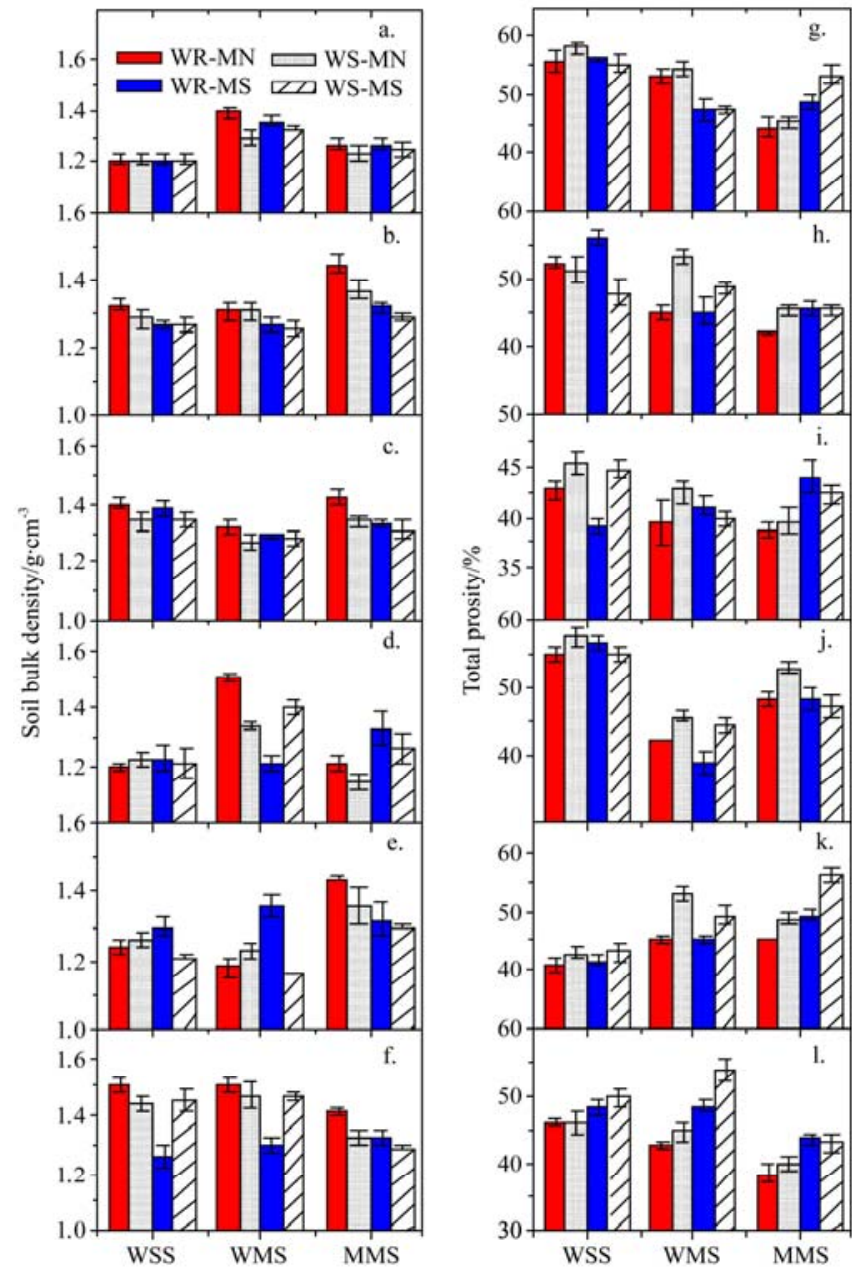

21.0 for Windows software package. The least significant difference (LSD) test was used to separate treatment means exhibiting significant differences at $p<0.05$.

\section{Results}

\subsection{Soil physical properties}

\subsubsection{Soil bulk density and porosity}

The soil bulk density of the $10-20 \mathrm{~cm}$ and $20-30 \mathrm{~cm}$ soil layers in the WS-MN group was decreased by $5.6 \%$ and $6.0 \%$, respectively, compared to that in the control WR-MN group $(p<0.05)$; in the WR-MS group compared to the control group, the soil bulk density was decreased by $8.7 \%$ in the $10-20 \mathrm{~cm}$ soil layer and by $6.7 \%$ in the $20-30 \mathrm{~cm}$ soil layer. In the WS-MS group compared to the control group, the soil bulk density exhibited a reduction of $10.4 \%$ in the $10-20 \mathrm{~cm}$ layer and $8.5 \%$ in the $20-30 \mathrm{~cm}$ layer (Figures 2a-2f) (2015-2016 and 2016-2017 growing seasons average). The soil bulk density of the $10-30 \mathrm{~cm}$ soil layer decreased by $7.6 \%$ over the two years (single-season or two-season subsoiling treatment average).
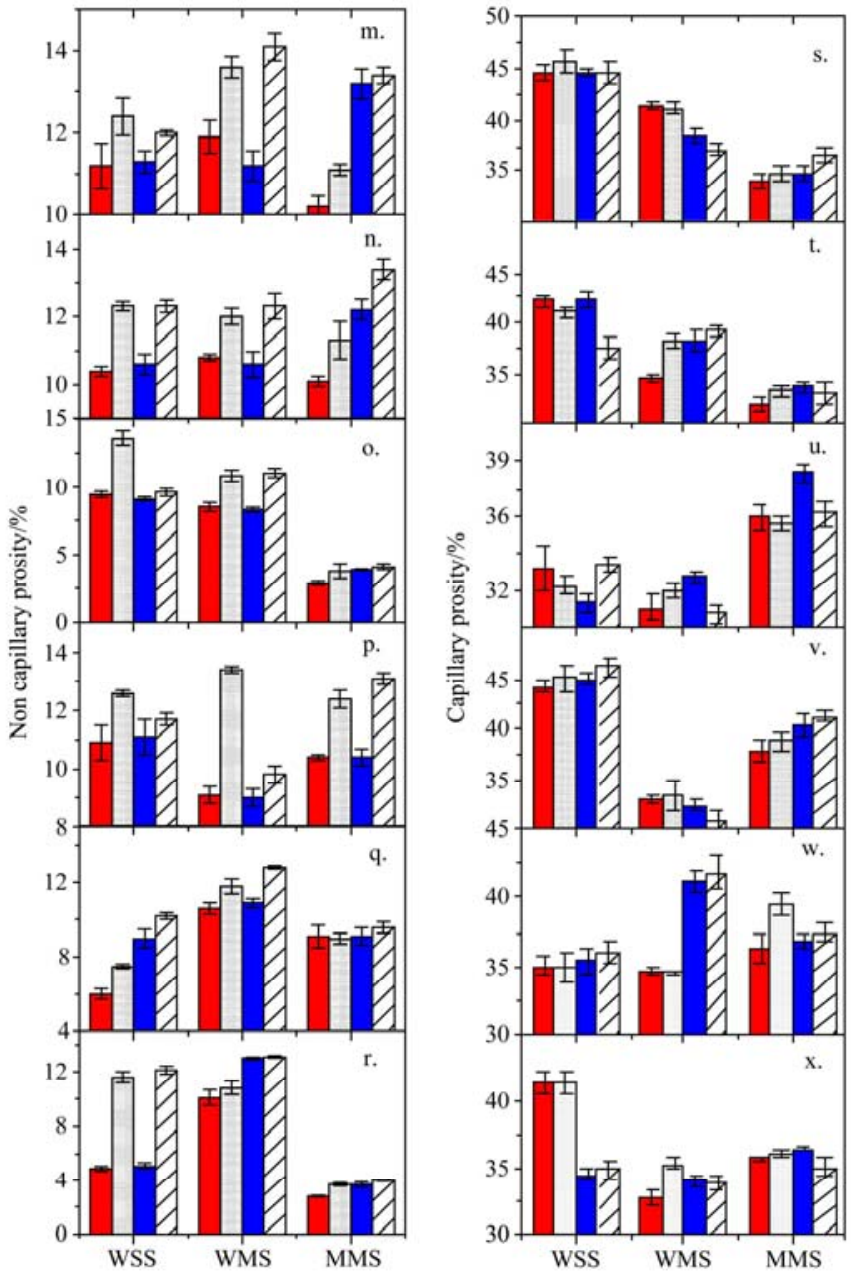

Note: $a, b, c, j, h, i, m, n, o, s, t$, and $u$ are data from 2015-2016; d, e, f, j, k, 1, p, q, r, v, w, and $\mathrm{x}$ are data from 2016-2017; a, g, m, s, d, j, p and v are data from the 0-10 $\mathrm{cm}$ soil layer; b, h, n, t, e, k, q, and w are data from the 10-20 cm soil layer; and c, i, o, u, f, l, r, and x are data from the 20-30 cm soil layer. WSS, WMS, and MMS represent the wheat seedling stage, wheat maturity stage and maize maturity stage, respectively. The error bars represent the standard errors of the mean.

Figure 2 Soil bulk density (a-f), soil porosity (g-l), noncapillary porosity (m-r), and capillary porosity ( $t-x)$ under different rotational tillage patterns

There are three types of soil porosity: void porosity, capillary porosity, and noncapillary porosity (Figures 2g-2l). Subsoiling can effectively increase the total porosity and the proportion of noncapillary porosity (Figures $2 \mathrm{~m}-2 \mathrm{q}$ ). The total porosity ratio in the $0-30 \mathrm{~cm}$ soil layer increased by $4.5 \%, 2.5 \%$, and $4.7 \%$, in the WR-MS, WS-MN, and WS-MS groups, respectively, compared to the WR-MN group while the noncapillary porosity ratio increased by $21.6 \%, 6.6 \%$, and $25.4 \%$, respectively. There were no statistically significant differences in capillary porosity among the treatment groups (Figures $2 \mathrm{~s}-2 \mathrm{x}$ ). The average soil bulk density decreased by $7.6 \%$, and the total porosity and noncapillary porosity increased by $10.7 \%$ and $12.2 \%$, respectively, in the two seasons of 
single or two seasons of subsoiling treatment compared to the control treatment.

\subsubsection{Soil water content}

Compared to WR-MS and WR-MN, WS-MN and WS-MS significantly increased the soil water content by an average of $14.7 \%$ in the $20-80 \mathrm{~cm}$ soil layer; however, none of the treatments significantly altered the soil water content below the $80 \mathrm{~cm}$ soil layer (Figures $3 \mathrm{a}$ and $3 \mathrm{c}$ ). Figures $2 \mathrm{~b}$ and $2 \mathrm{~d}$ show that the water content in the $20-140 \mathrm{~cm}$ soil layer increased by $16.9 \%$ and $11.1 \%$, in the WT-MS and MS-WS groups, respectively, compared with the WR-MN group. The difference between the WR-MS and WS-MS groups was not statistically significant $(p>0.05)$. The water content in the $20-140 \mathrm{~cm}$ soil layer of the WS-MN group increased by $12.1 \%$ after the maize season. According to the above results, under the one-year double cropping system of winter wheat and summer maize in the Haihe Plain of China, the soil water content after a single season or two seasons of subsoiling tillage can be significantly increased below $20 \mathrm{~cm}$.

\subsubsection{Soil temperature}

During the prewinter stage of wheat, the $10 \mathrm{~cm}$ ground temperature of the WS-MN and WS-MS groups was increased by $1.8^{\circ} \mathrm{C}(22.1 \%)$ compared to that of the WR-MS and WR-MN groups with RT. In contrast, the average ground temperature decreased by $0.9{ }^{\circ} \mathrm{C}$ during the overwintering period and increased by $3.2^{\circ} \mathrm{C}$ from the green to the mature stage. During the maize season, the WS-MS and WR-MS treatments with subsoiling tillage increased the average $10 \mathrm{~cm}$ ground temperature by $2.3^{\circ} \mathrm{C}$ in comparison with the control WR-MN treatment. The ground temperature of the WS-MN group was $0.8^{\circ} \mathrm{C}$ higher than that of the WR-MN group (Figure 4). Higher ground temperatures can accelerate the formation of the dry soil layer and help reduce soil evaporation and increase water storage after irrigation or high-intensity precipitation.

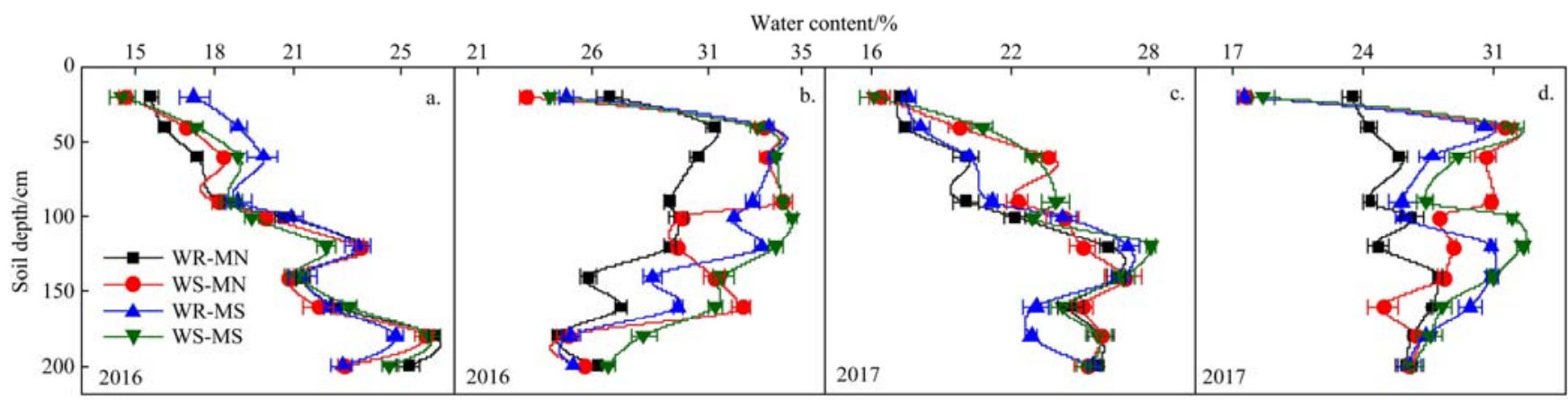

Figure 3 Water content in the $0-200 \mathrm{~cm}$ soil layer at the wheat maturity ( $\mathrm{a}$ and $\mathrm{c}$ ) and maize maturity (b and d) stages under different rotational tillage patterns

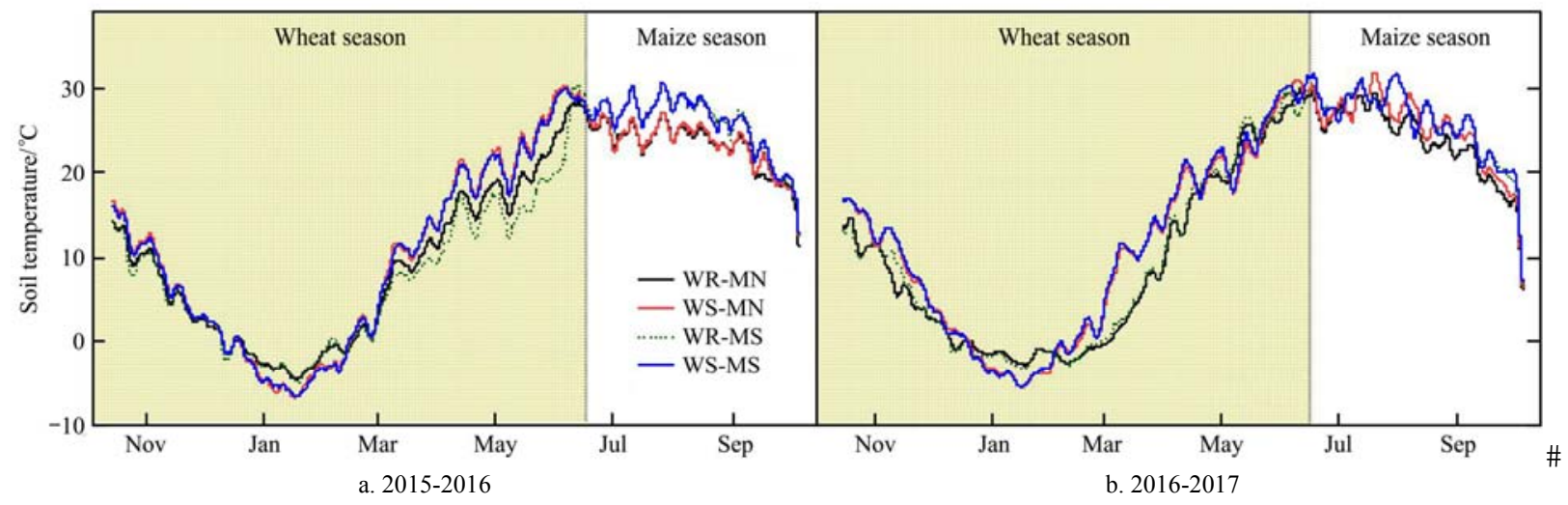

Figure 4 Average temperature at a soil depth of $10 \mathrm{~cm}$ over $5 \mathrm{~d}$ under different rotational tillage patterns

\subsection{Distribution of nitrate nitrogen and ammonium nitrogen in soil}

The ammonium nitrogen content soil layer increased by $35.5 \%$ on average in the $0-20 \mathrm{~cm}$ soil in the WS-MS and WS-MN groups compared to the control WR-MN group, while it decreased by $28.7 \%$ in the $20-100 \mathrm{~cm}$ soil layer (Figures 5a, 5c, 5e, and $5 \mathrm{~g}$ ). The nitrate nitrogen content was on average $11.5 \%$ lower than that in the WR-MN group in the $0-100 \mathrm{~cm}$ soil layer. During the maize season, the average ammonium nitrogen content increased by $18.6 \%$ in the $0-20 \mathrm{~cm}$ soil layer, decreased by $16.8 \%$ in the $20-100 \mathrm{~cm}$ soil layer, and decreased by $13.5 \%$ in the $0-100 \mathrm{~cm}$ soil layer. The different tillage treatments had no significant effects on the nitrate nitrogen content or ammonium nitrogen content in soil below $100 \mathrm{~cm}$ (Figures 5b, 5d, and 5f).

3.3 Soil organic carbon, microbial carbon, and active microbial populations

During the wheat season, the SOC and SMBC contents in the
$15-30 \mathrm{~cm}$ soil were significantly increased by $10.2 \%$ and $14.8 \%$ in the WS-MS and WS-MN groups, respectively, compared to the WR-MN group. However, there were no significant differences in SOC or SMBC content in the $0-15 \mathrm{~cm}$ soil between the WS-MS and WS-MN groups. During the maize season, the SOC content in the $15-30 \mathrm{~cm}$ soil was increased by $27.2 \%$ and $24.9 \%$ in the WS-MS and WR-MS groups, respectively, compared to the control WR-MN group. The SMBC content increased by $12.1 \%$ in the WS-MS group and $17.4 \%$ in the WR-MS group. Moreover, in the WS-MN groups, the SOC and SMBC contents in the $15-30 \mathrm{~cm}$ soil increased by $9.9 \%$ and $6.4 \%$, respectively (Figures $6 \mathrm{a}-6 \mathrm{~h}$ ). The different tillage treatments had no obvious effects on the soil microbial quotient but had significant effects on the number of active microbes in the soil. The WS-MS and WR-MS treatments significantly increased the number of active microbes in the 0 $30 \mathrm{~cm}$ soil layer, which was $28.9 \%$ higher on average than that in the control WR-MN group (Figures 6i-6p). 


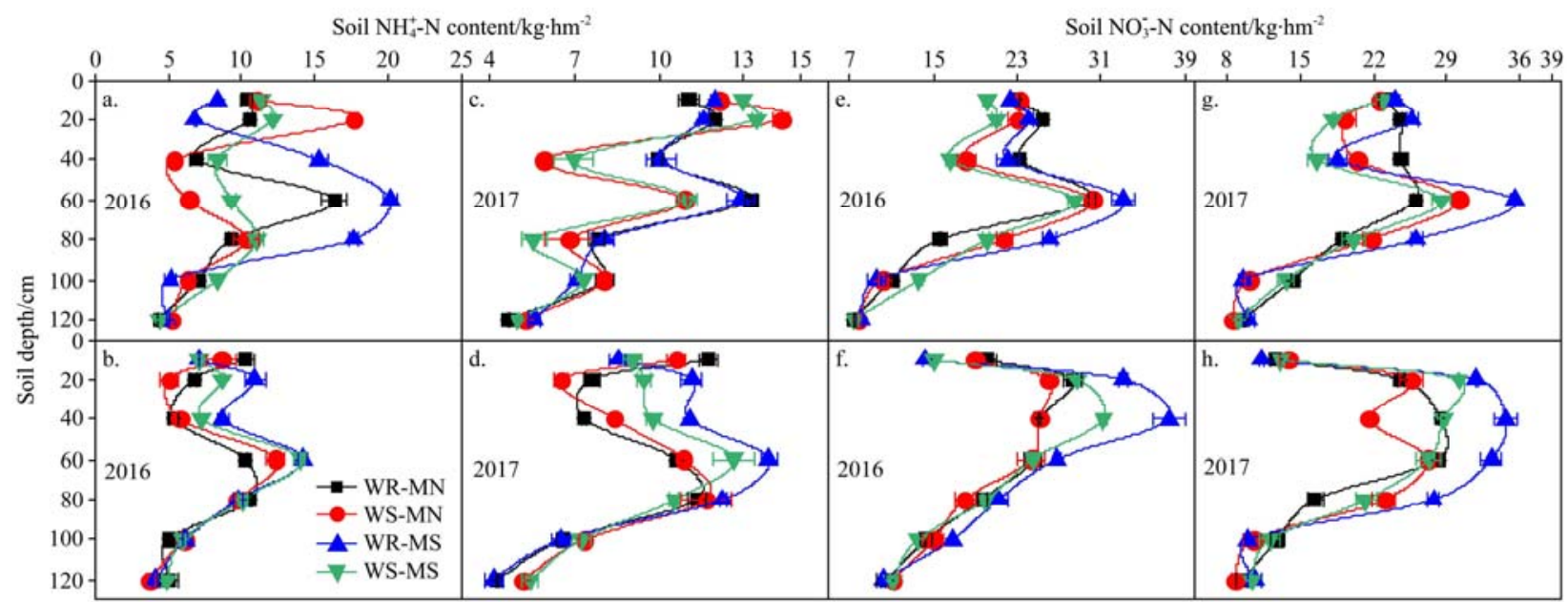

Note: $\mathrm{a}, \mathrm{c}, \mathrm{e}$, and $\mathrm{g}$ are data measured at wheat maturity; $\mathrm{b}, \mathrm{d}, \mathrm{f}$, and $\mathrm{h}$ are data measured at maize maturity.

Figure 5 Distribution of ammonium nitrogen (a-d) and nitrate nitrogen (e-h) in 0-120 cm soil under different rotational tillage patterns

Table 2 Total soil organic carbon content, microbial carbon content, microorganism quotient, and active microorganism number under different rotational tillage patterns

\begin{tabular}{|c|c|c|c|c|c|c|c|c|c|c|}
\hline \multirow[t]{2}{*}{ Year } & \multirow{2}{*}{ Growth season } & \multirow{2}{*}{ Treatment } & \multicolumn{2}{|c|}{$\begin{array}{l}\text { Total organic carbon } \\
\text { content } / \mathrm{mg}^{\prime} \cdot \mathrm{kg}^{-1}\end{array}$} & \multicolumn{2}{|c|}{$\begin{array}{l}\text { Microbial biomass carbon } \\
\text { content } / \mathrm{mg}^{-1} \mathrm{~kg}^{-1}\end{array}$} & \multicolumn{2}{|c|}{$\begin{array}{l}\text { Microorganism } \\
\text { quotient } / \%\end{array}$} & \multicolumn{2}{|c|}{$\begin{array}{l}\text { Active microorganism } \\
\text { number } / \mathrm{mg}^{\prime} \mathrm{kg}^{-1}\end{array}$} \\
\hline & & & $0-15 \mathrm{~cm}$ & $15-30 \mathrm{~cm}$ & $0-15 \mathrm{~cm}$ & $15-30 \mathrm{~cm}$ & $0-15 \mathrm{~cm}$ & $15-30 \mathrm{~cm}$ & $0-15 \mathrm{~cm}$ & $15-30 \mathrm{~cm}$ \\
\hline \multirow{8}{*}{$2015-2016$} & \multirow{4}{*}{ Wheat } & WR-MN & $20.38^{\mathrm{a}}$ & $20.95^{\mathrm{b}}$ & $166.21^{\mathrm{ab}}$ & $171.21^{\mathrm{b}}$ & $8.16^{\mathrm{a}}$ & $8.17^{\mathrm{a}}$ & $95.37^{\mathrm{a}}$ & $44.15^{\mathrm{c}}$ \\
\hline & & WS-MN & $21.06^{\mathrm{a}}$ & $23.25^{\mathrm{a}}$ & $164.32^{\mathrm{ab}}$ & $181.21^{\mathrm{a}}$ & $7.80^{\mathrm{a}}$ & $7.79^{\mathrm{a}}$ & $100.12^{\mathrm{a}}$ & $69.74^{\mathrm{a}}$ \\
\hline & & WS-MN & $19.95 \mathrm{a}^{\mathrm{b}}$ & $21.01^{\mathrm{b}}$ & $170.12^{\mathrm{a}}$ & $171.67^{b}$ & $8.53^{\mathrm{a}}$ & $8.17^{\mathrm{a}}$ & $98.74^{\mathrm{a}}$ & $55.16^{\mathrm{b}}$ \\
\hline & & WR-MS & $19.14 a^{b}$ & $22.97^{\mathrm{a}}$ & $163.24^{\mathrm{ab}}$ & $188.32^{\mathrm{a}}$ & $8.53^{\mathrm{a}}$ & $8.19^{\mathrm{a}}$ & $97.63^{\mathrm{a}}$ & $64.32^{\mathrm{a}}$ \\
\hline & \multirow{4}{*}{ Maize } & WR-MN & $16.23^{\mathrm{b}}$ & $13.97^{\mathrm{c}}$ & $158.6^{\mathrm{b}}$ & $103.22^{b}$ & $9.2^{\mathrm{a}}$ & $7.21^{\mathrm{a}}$ & $25.3^{\mathrm{b}}$ & $20.16^{\mathrm{b}}$ \\
\hline & & WS-MN & $19.22^{\mathrm{a}}$ & $14.59^{\mathrm{b}}$ & $165.08^{\mathrm{a}}$ & $106.89^{\mathrm{a}}$ & $9.11^{\mathrm{a}}$ & $7.5^{\mathrm{a}}$ & $30.1^{\mathrm{a}}$ & $30.14^{\mathrm{a}}$ \\
\hline & & WS-MN & $19.06^{\mathrm{a}}$ & $15.83^{\mathrm{b}}$ & $163.97^{\mathrm{a}}$ & $108.9^{\mathrm{a}}$ & $9.3^{\mathrm{a}}$ & $7.27^{\mathrm{a}}$ & $31.7^{\mathrm{a}}$ & $30.04^{\mathrm{a}}$ \\
\hline & & WR-MS & $19.39^{\mathrm{a}}$ & $16.97^{\mathrm{a}}$ & $163.2^{\mathrm{a}}$ & $109.2^{\mathrm{a}}$ & $9.09^{\mathrm{a}}$ & $7.14^{\mathrm{a}}$ & $30.9^{\mathrm{a}}$ & $29.61^{\mathrm{a}}$ \\
\hline \multirow{7}{*}{ 2016-2017 } & \multirow{4}{*}{ Wheat } & WR-MN & $17.25^{\mathrm{ab}}$ & $14.31^{\mathrm{c}}$ & $158.2^{\mathrm{a}}$ & $105.61^{\mathrm{c}}$ & $9.17^{\mathrm{b}}$ & $7.38^{\mathrm{a}}$ & $25.32^{\mathrm{a}}$ & $5.39^{\mathrm{c}}$ \\
\hline & & WS-MN & $18.12^{\mathrm{a}}$ & $19.26^{\mathrm{a}}$ & $151.3^{\mathrm{a}}$ & $132.3^{\mathrm{a}}$ & $8.34^{\mathrm{a}}$ & $6.87^{\mathrm{ab}}$ & $25.61^{\mathrm{a}}$ & $7.36^{\mathrm{a}}$ \\
\hline & & WS-MN & $17.63^{\mathrm{ab}}$ & $14.97^{\mathrm{c}}$ & $156.3^{\mathrm{a}}$ & $105.46^{\mathrm{c}}$ & $8.87^{\mathrm{b}}$ & $7.04^{\mathrm{a}}$ & $25.48^{\mathrm{a}}$ & $5.04^{\mathrm{c}}$ \\
\hline & & WR-MS & $17.95^{\mathrm{ab}}$ & $18.3^{\mathrm{ab}}$ & $155.9^{\mathrm{a}}$ & $124.31^{\mathrm{b}}$ & $8.69^{\mathrm{a}}$ & $6.79^{\mathrm{ab}}$ & $26.03^{\mathrm{a}}$ & $6.11^{\mathrm{ab}}$ \\
\hline & \multirow{3}{*}{ Maize } & WR-MN & $22.15^{\mathrm{b}}$ & $22.16^{\mathrm{c}}$ & $175.34^{d}$ & $185.34^{\mathrm{d}}$ & $7.92^{\mathrm{a}}$ & $8.36^{\mathrm{a}}$ & $16.6^{\mathrm{b}}$ & $32.08^{\mathrm{c}}$ \\
\hline & & WS-MN & $25.69^{\mathrm{b}}$ & $30.14^{\mathrm{a}}$ & $204.6^{\mathrm{b}}$ & $214.69^{\mathrm{ab}}$ & $7.96^{\mathrm{a}}$ & $7.12^{\mathrm{ab}}$ & $20.50^{\mathrm{a}}$ & $42.84^{\mathrm{a}}$ \\
\hline & & WR-MS & $27.92^{\mathrm{a}}$ & $28.14^{\mathrm{a}}$ & $215.6^{\mathrm{a}}$ & $229.64^{\mathrm{a}}$ & $7.72^{\mathrm{a}}$ & $8.16^{\mathrm{a}}$ & $20.9^{\mathrm{a}}$ & $41.06^{\mathrm{a}}$ \\
\hline
\end{tabular}

Note: Values followed by a different lowercase letter within the same column are significantly $\overline{\text { different at the }} \overline{0.05 \text { level. }}$
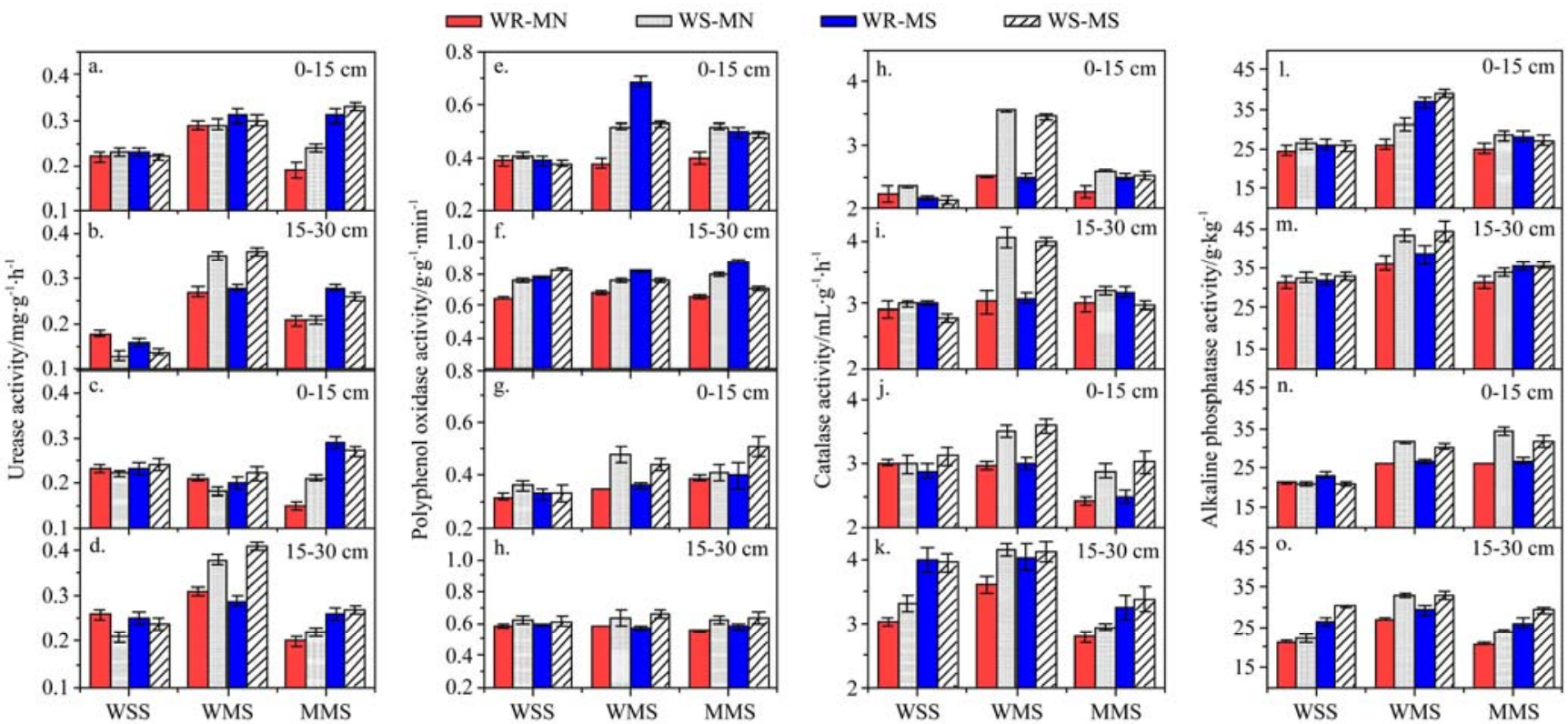

Note: a, e, i, m, c, g, k, and o are data collected in the wheat season; b, f, j, n, d, h, l, and p are data collected in the maize season; a, b, e, f, i, j, m, and $\mathrm{n}$ are data from 2015-2016; c, d, g, h, j, k, l, o, and p are data from 2016-2017. WSS, WMS, and MMS represent the wheat seedling stage, wheat maturity stage, and maize maturity stage, respectively. The error bars represent the standard errors of the mean.

Figure 6 Effects on soil enzyme activities under different rotational tillage patterns 


\subsection{Soil enzyme activities and respiration rate}

\subsubsection{Soil enzyme activities}

The total urease activity in the $0-30 \mathrm{~cm}$ soil was increased by $19 \%$ in WS-MN group compared with the WR-MN group (Figures 6a-6d). The WR-MS and WS-MS treatments did not affect the URE activity in the $0-15 \mathrm{~cm}$ soil but significantly increased the URE activity in the $15-30 \mathrm{~cm}$ soil by $6.8 \%$ on average in the two wheat-maize planting seasons. In the WS-MN, WR-MS, and WS-MS groups, the PPO activity in the $0-30 \mathrm{~cm}$ soil was increased by $17.3 \%, 16.6 \%$, and $18.95 \%$, respectively (Figures 6e-6p). CAT activity was increased by $18.8 \%, 9.1 \%$, and $21.9 \%$ (Figures 6i-61), and ALP was increased by $13.9 \%, 11.1 \%$, and $21.0 \%$ (Figures $6 \mathrm{~m}-6 \mathrm{p}$ ) in the WS-MN, WR-MS, and WS-MS groups, respectively, compared to the control WR-MN treatment in the two wheat-maize seasons. Further comparison of the WS-MN and WR-MS single-season subsoiling treatments demonstrated that the activity of URE activity in soil increased significantly after wheat

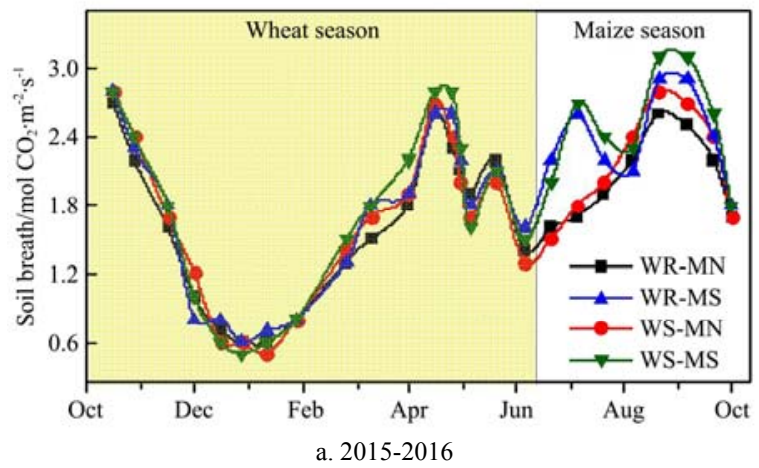

season subsoiling, but there was no significant difference in the activity of other enzymes. In the two-season subsoiling treatment WS-MS, there was no significant change in other indices. The results indicated that subsoiling tillage effectively increased soil enzyme activity, which improved soil chemical properties, promoted the utilization of organic matter, and accelerated the nutrient cycle.

\subsubsection{Soil respiration rate}

Subsoiling notably increased the soil respiration rate (Figure 7) Compared to WR-MS and WR-MN, WS-MS and WS-MN led to an increase in the soil respiration rate of $7.5 \%$ on average in the two wheat seasons and $19.5 \%$ on average in the two maize seasons; however, the difference between the effects of the WS-MS and WS-MN treatments was not statistically significant. In addition, subsoiling during the wheat season had no significant effect on the soil respiration rate in the maize season in the WS-MN group compared to the control WR-MN group.

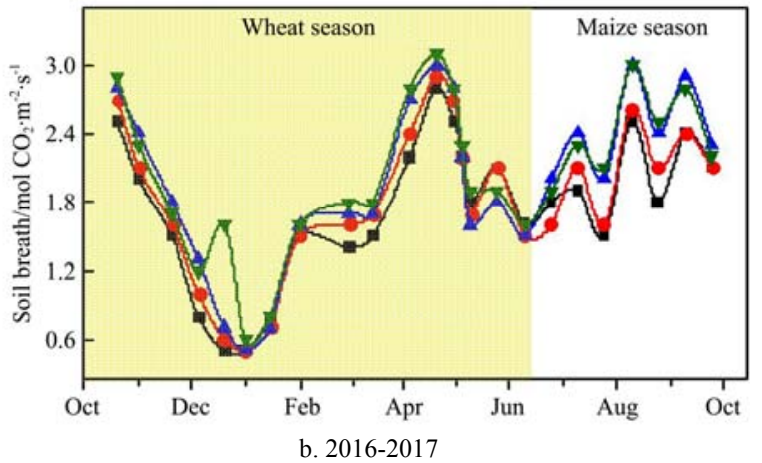

Figure 7 Respiration dynamics in $10 \mathrm{~cm}$ soil under different rotational tillage patterns

3.5 Wheat-maize double cropping yield and WUE under different rotational tillage patterns

\subsubsection{Yield and WUE of maize and wheat}

Compared to the control WR-MN treatment, the WS-MS treatment had the highest annual yield increase (i.e., $10.6 \%$ in the two growing seasons), followed by the single subsoiling WR-MS and WS-MN treatments, with an average increase of $7.5 \%$ (Table 1). Compared to RT (WR-MN and WR-MS), subsoiling tillage (WS-MN and WS-MS) during the wheat season significantly increased the wheat yield by $3.9 \%$ on average in the two wheat seasons. Moreover, the WS-MN treatment significantly increased maize yield in the same year by $7.2 \%$. Compared with the WR-MN treatment, subsoiling (WS-MS and WR-MS) during the maize season notably increased maize yield by an average of $12.1 \%$ in the two maize seasons. Subsoiling significantly reduced water consumption during the crop growth period. The annual water consumption showed the greatest reduction $(6.5 \%)$ in the WS-MS group compared to the WR-MN group during the two seasons and a reduction of $4.1 \%$ on average in the single subsoiling
WS-MN and WR-MS treatments compared to the WR-MN group. Furthermore, crop WUE in the whole year and the single wheat or maize seasons also significantly increased. The annual crop WUE under subsoiling tillage in both seasons showed the greatest increase $(18.3 \%)$, and the WUE in the single-season subsoiling treatments WS-MN and WR-MS increased by an average of $12.1 \%$.

3.5.2 Nitrogen uptake (TNA) of wheat and maize and partial fertilizer productivity (PFP)

The single-season subsoiling treatments WR-MS and WS-MN and the two-season subsoiling treatment WS-MS significantly increased wheat and maize annual nitrogen uptake. Compared to WR-MN, WR-MS, WS-MS, and WS-MN increased the annual nitrogen uptake of crops by $14.3 \%, 11.4 \%$, and $5.1 \%$, respectively. In addition, subsoiling significantly improved PFP. The average annual utilization efficiencies of $\mathrm{N}, \mathrm{P}_{2} \mathrm{O}_{5}$, and $\mathrm{K}_{2} \mathrm{O}$ in the WR-MS, WS-MN, and WS-MS groups increased by $8.63 \%, 8.46 \%$, and $8.54 \%$, respectively, compared with those in the WR-MN group (Table 4).

Table 3 Yield, farmland evapotranspiration, and WUE of wheat and maize under different rotational tillage patterns

\begin{tabular}{|c|c|c|c|c|c|c|c|c|c|c|}
\hline \multirow{2}{*}{ Year } & \multirow{2}{*}{ Treatment } & \multicolumn{3}{|c|}{ Yield $/ \mathrm{kg} \cdot \mathrm{hm}^{-2}$} & \multicolumn{3}{|c|}{ Water consumption/mm } & \multicolumn{3}{|c|}{$\mathrm{WUE} / \mathrm{kg} \cdot \mathrm{hm}^{-2} \cdot \mathrm{mm}^{-1}$} \\
\hline & & Wheat & Maize & Whole year & Wheat & Maize & Whole year & Wheat & Maize & Whole year \\
\hline \multirow{3}{*}{$2015-2016$} & WR-MN & $7302.3^{\mathrm{b}}$ & $9078.3^{\mathrm{d}}$ & $16380.6^{\mathrm{c}}$ & $431.0^{\mathrm{a}}$ & $429.9^{\mathrm{a}}$ & $860.9^{\mathrm{a}}$ & $16.9^{\mathrm{b}}$ & $21.1^{\mathrm{c}}$ & $19.0^{\mathrm{b}}$ \\
\hline & WR-MS & $7387.4^{\mathrm{b}}$ & $10089.9^{\mathrm{ab}}$ & $17477.3^{\mathrm{ab}}$ & $434.6^{\mathrm{a}}$ & $392.4^{\mathrm{c}}$ & $827.0^{\mathrm{b}}$ & $17.0^{\mathrm{b}}$ & $25.7^{\mathrm{a}}$ & $21.1^{\mathrm{a}}$ \\
\hline & WS-MS & $8096.4^{\mathrm{a}}$ & $10178.5^{\mathrm{a}}$ & $18274.9^{\mathrm{a}}$ & $415.5^{\mathrm{b}}$ & $386.1^{\mathrm{c}}$ & $801.6^{\mathrm{c}}$ & $19.5^{\mathrm{a}}$ & $26.4^{\mathrm{a}}$ & $22.8^{\mathrm{a}}$ \\
\hline \multirow{3}{*}{$2016-2017$} & WR-MN & $7711.6^{\mathrm{b}}$ & $8996.9^{c}$ & $16708.5^{\mathrm{c}}$ & $419.7^{\mathrm{a}}$ & $421.5^{\mathrm{a}}$ & $841.2^{\mathrm{a}}$ & $18.4^{\mathrm{b}}$ & $21.3^{\mathrm{c}}$ & $19.9^{\mathrm{b}}$ \\
\hline & WR-MS & $7805.1^{\mathrm{b}}$ & $10201.3^{\mathrm{a}}$ & $18006.4^{\mathrm{ab}}$ & $413.9^{\mathrm{ab}}$ & $392.2^{\mathrm{c}}$ & $806.1^{\mathrm{b}}$ & $18.9^{\mathrm{b}}$ & $26.0^{\mathrm{a}}$ & $22.3^{\mathrm{a}}$ \\
\hline & WS-MS & $8244.3^{\mathrm{a}}$ & $10064.1^{\mathrm{ab}}$ & $18308.4^{\mathrm{a}}$ & $399.9^{c}$ & $389.3^{c}$ & $789.2^{\mathrm{c}}$ & $20.6^{\mathrm{a}}$ & $25.9^{\mathrm{a}}$ & $23.2^{\mathrm{a}}$ \\
\hline
\end{tabular}

Note: Values followed by different lowercase letters within the same column are significantly different at the 0.05 level. 
Table 4 Nitrogen uptake (NU) of wheat and maize and partial fertilizer productivity (PFP) under different rotational tillage patterns

\begin{tabular}{|c|c|c|c|c|c|c|c|c|c|c|c|c|c|}
\hline \multirow{3}{*}{ Year } & \multirow{3}{*}{ Treatment } & \multirow{2}{*}{\multicolumn{3}{|c|}{$\mathrm{NU} / \mathrm{kg} \cdot \mathrm{hm}^{-2}$}} & \multicolumn{9}{|c|}{$\mathrm{PFP} / \mathrm{kg} \cdot \mathrm{kg}^{-1}$} \\
\hline & & & & & \multicolumn{3}{|c|}{ Wheat } & \multicolumn{3}{|c|}{ Maize } & \multicolumn{3}{|c|}{ Whole year } \\
\hline & & Wheat & Maize & Whole year & $\mathrm{N}$ & $\mathrm{P}_{2} \mathrm{O}_{5}$ & $\mathrm{~K}_{2} \mathrm{O}$ & $\mathrm{N}$ & $\mathrm{P}_{2} \mathrm{O}_{5}$ & $\mathrm{~K}_{2} \mathrm{O}$ & $\mathrm{N}$ & $\mathrm{P}_{2} \mathrm{O}_{5}$ & $\mathrm{~K}_{2} \mathrm{O}$ \\
\hline \multirow{4}{*}{$2015-2016$} & WR-MN & $239.6^{\mathrm{b}}$ & $284.1^{\mathrm{c}}$ & $284.1^{\mathrm{a}}$ & $30.4^{\mathrm{b}}$ & $64.9^{\mathrm{b}}$ & $64.9^{\mathrm{b}}$ & $40.3^{\mathrm{c}}$ & $75.7^{\mathrm{b}}$ & $100.9^{\mathrm{b}}$ & $35.2^{\mathrm{b}}$ & $70.5^{\mathrm{c}}$ & $80.9^{\mathrm{b}}$ \\
\hline & WS-MN & $255.1^{\mathrm{a}}$ & $304.6^{\mathrm{ab}}$ & $304.6^{\mathrm{b}}$ & $33.6^{\mathrm{a}}$ & $71.7^{\mathrm{a}}$ & $71.7^{\mathrm{a}}$ & $43.6^{\mathrm{ab}}$ & $81.7^{\mathrm{a}}$ & $108.9^{\mathrm{a}}$ & $38.4^{\mathrm{a}}$ & $76.8^{\mathrm{ab}}$ & $88.2^{\mathrm{a}}$ \\
\hline & WR-MS & $238.9^{\mathrm{bb}}$ & $329.9^{\mathrm{a}}$ & $329.9^{\mathrm{a}}$ & $30.8^{\mathrm{b}}$ & $65.7^{\mathrm{b}}$ & $65.7^{\mathrm{b}}$ & $44.8^{\mathrm{a}}$ & $84.1^{\mathrm{a}}$ & $112.1^{\mathrm{a}}$ & $37.6^{\mathrm{ab}}$ & $75.2^{\mathrm{ab}}$ & $86.3^{\mathrm{a}}$ \\
\hline & WS-MS & $254.6^{\mathrm{a}}$ & $314.3^{\mathrm{ab}}$ & $314.3^{\mathrm{ab}}$ & $33.7^{\mathrm{a}}$ & $72.0^{\mathrm{a}}$ & $72.0^{\mathrm{a}}$ & $45.2^{\mathrm{a}}$ & $84.8^{\mathrm{a}}$ & $113.1^{\mathrm{a}}$ & $39.3^{\mathrm{a}}$ & $78.6^{\mathrm{a}}$ & $90.2^{\mathrm{a}}$ \\
\hline \multirow{4}{*}{$2016-2017$} & WR-MN & $251.6^{\mathrm{b}}$ & $286.7^{\mathrm{c}}$ & $286.7^{\mathrm{c}}$ & $32.1^{\mathrm{ab}}$ & $68.5^{\mathrm{b}}$ & $68.5^{\mathrm{b}}$ & $40.0^{\mathrm{c}}$ & $75.0^{\mathrm{c}}$ & $100.0^{\mathrm{c}}$ & $35.9^{\mathrm{b}}$ & $71.9^{\mathrm{b}}$ & $82.5^{\mathrm{b}}$ \\
\hline & WS-MN & $270.3^{\mathrm{a}}$ & $295.3^{\mathrm{b}}$ & $295.3^{\mathrm{b}}$ & $34.4^{\mathrm{a}}$ & $73.3^{\mathrm{a}}$ & $73.3^{\mathrm{a}}$ & $42.5^{\mathrm{ab}}$ & $79.8^{\mathrm{ab}}$ & $106.4^{\mathrm{ab}}$ & $38.3^{\mathrm{a}}$ & $76.6^{\mathrm{a}}$ & $88.0^{\mathrm{a}}$ \\
\hline & WR-MS & $255.4^{\mathrm{b}}$ & $322.5^{\mathrm{a}}$ & $322.5^{\mathrm{a}}$ & $32.5^{\mathrm{ab}}$ & $69.4^{\mathrm{b}}$ & $69.4^{\mathrm{b}}$ & $45.3^{\mathrm{a}}$ & $85.0^{\mathrm{a}}$ & $113.3^{\mathrm{a}}$ & $38.7^{\mathrm{a}}$ & $77.4^{\mathrm{a}}$ & $88.9^{\mathrm{a}}$ \\
\hline & WS-MS & $289.7^{\mathrm{a}}$ & $321.4^{\mathrm{ab}}$ & $321.4^{\mathrm{a}}$ & $34.4^{\mathrm{a}}$ & $73.3^{\mathrm{a}}$ & $73.3^{\mathrm{a}}$ & $44.7^{\mathrm{a}}$ & $83.9^{\mathrm{a}}$ & $111.8^{\mathrm{a}}$ & $39.4^{\mathrm{a}}$ & $78.7^{\mathrm{a}}$ & $90.4^{\mathrm{a}}$ \\
\hline
\end{tabular}

\section{Discussion}

4.1 Effects of different rotational tillage patterns on soil physical properties

Studies have shown that, compared to traditional tillage, conservation tillage (represented by less or no-tillage) can effectively improve the physical properties of soil, increase the water holding capacity, simplify operations, and reduce the mechanical input; therefore, it is widely used in practical production $^{[6,45,46]}$. For example, in many arid and semiarid areas, no-tillage or shallow RT is adopted to prevent frequent and large-scale disturbance of soil ${ }^{[23,47]}$; however, in some areas, tillage is adopted year after year to obtain higher yields or increased soil moisture content for sowing ${ }^{[48]}$. However, the disadvantages of the long-term use of a single tillage pattern have gradually emerged ${ }^{[15,49]}$; for example, no-tillage in successive years causes the plough layer to become shallow, which restricts the penetration of the root system ${ }^{[50]}$. Mechanical tillage in successive years causes destruction of the soil aggregate structure, which leads to wind erosion ${ }^{[51]}$. Therefore, through the reasonable allocation of soil tillage methods, including ploughing, rotating, and no-tillage, a scientific rotation pattern is expected to overcome the disadvantages of a long-term single tillage system.

The current results show that under the winter wheat-summer maize double cropping system in the Haihe Plain, the application of subsoiling tillage could significantly increase soil porosity and reduce the soil bulk density ${ }^{[48,52]}$. The soil bulk density in the $10-30 \mathrm{~cm}$ soil layer decreased by $4.7 \%$ on average under single-season subsoiling with the WS-MN and WR-MS groups and two season subsoiling in the WS-MS group compared with conventional tillage in the WR-MN group, and the soil total porosity and noncapillary porosity in $0-30 \mathrm{~cm}$ soil were increased by $3.8 \%$ and $17.9 \%$, respectively. This result supported a previous report that soil physical properties can be optimized by introducing subsoiling technology into the rotation system ${ }^{[46,48]}$. However, studies on the Chinese Loess Plateau have shown that the alternative application of no-tillage and RT is more conducive to increasing soil porosity and changing soil physical properties ${ }^{[53]}$. It can be seen that subsoiling plays an important role in the improvement of the rotation system. It is important to improve the soil compactness and upward movement of the plough pan caused by single no-tillage or shallow rotation tillage for many years in the Haihe Plain.

4.2 Effects of different rotational tillage patterns on water and heat properties in soil and the respiration rate of farmland

Many studies have shown that the tillage method plays an important role in changing water and heat properties in soil ${ }^{[54-56]}$. For example, no-tillage conserves more soil water by increasing water infiltration and reducing evaporation ${ }^{[14]}$. Subsoiling can promote root growth, improve soil water infiltration, and increase water availability for crops ${ }^{[24,57]}$. No-tillage reduces the thermal conductivity of the soil, which leads to a smaller variation in the amplitude of soil temperature ${ }^{[54]}$. However, due to the increase in soil porosity, subsoiling can increase the variation amplitude of soil temperature ${ }^{[56]}$

This study showed that annual rotation tillage with subsoiling as the core can significantly increase the soil water content in the middle and deep soil layers $(20-120 \mathrm{~cm})$. Specifically, over the two experimental years, the precipitation in summer was more than that in a normal year, and the water storage capability under subsoiling increased significantly. The study also showed that rotation tillage with subsoiling increased the variation amplitude of soil temperature and average ground temperature in the $10 \mathrm{~cm}$ soil layer. Annual rotation tillage with subsoiling as the core can guarantee the water demand for crop growth in the later period through increased soil water storage capacity, which is also consistent with the results of crop yield in this study. In addition, rotation tillage with subsoiling as the core improved the soil respiration rate, possibly due to the higher soil moisture content and ground temperature under rotation tillage, which also confirmed the results of a previous study ${ }^{[58]}$.

4.3 Effects of different rotational tillage patterns on soil nutrients and soil enzyme activities

Studies have shown that tillage methods have significant effects on soil enzyme activity and nutrients ${ }^{[59,60]}$. Subsoiling treatment improves enzyme activities in soil; however, CAT enzyme activity was reduced in the current study ${ }^{[61,52,53]}$. In addition, rotation with ploughing tillage/no-tillage and subsoiling tillage/ploughing tillage provides an optimal SOC distribution in the $0-60 \mathrm{~cm}$ soil layer ${ }^{[49]}$. The current study indicated that rotation tillage with subsoiling significantly increased the soil organic carbon content and the enzyme activities of urease, catalase, and microbial carbon in the $15-30 \mathrm{~cm}$ soil layer, which promoted nutrient utilization efficiency by crops. However, the results of the study are not consistent with the results of references ${ }^{[62,63]}$, which showed that no-tillage can improve the soil organic carbon content. Nitrate nitrogen content in the $0-100 \mathrm{~cm}$ soil was reduced by $13.5 \%$ on average, which may have been due to improved soil physical properties resulting from annual rotation tillage with subsoiling of maize. An appropriate soil porosity provides sufficient space for water and nutrients in the soil, and a higher soil porosity accelerates the decomposition of soil 
aggregates and is suitable for aerobic microorganism activities, thereby improving nutrient absorption by crops.

4.4 Effects of different rotational tillage patterns on crop yield and water and fertilizer utilization

It is undeniable that the long-term single tillage method (such as continuous no-tillage) plays a beneficial role in maintaining farmland ecosystems and soil functions ${ }^{[62]}$. However, the long-term single tillage practice is harmful to crop yield and water and fertilizer utilization, which has been proven by studies carried out in the Chinese Loess Plateau with poor soil ${ }^{[5,15,24,53]}$, in eastern Germany with sand land ${ }^{[1]}$, and in many other areas. Therefore, many studies have focused on the application of different rotation patterns to improve crop yield and water and fertilizer utilization. Rotation tillage for 10 consecutive years performed in the Loess Plateau of China showed that the annual crop yield and WUE were effectively increased under a rotation pattern with subsoiling/rotary tillage and subsoiling/no-tillage compared to single tillage with no-tillage or ST in the wheat-maize cropping system ${ }^{[49]}$.

The current study showed that single or two-season subsoiling increased the annual crop yield by $7.5 \%-10.6 \%$ in the wheat-maize double cropping system in the Haihe Plain and significantly improved the water and fertilizer production efficiency. After subsoiling in the wheat season, regardless of tillage or subsoiling in the maize season, a higher maize yield was achieved. However, due to variations in soil type, precipitation, climate, and planting systems, different soil tillage methods, especially double cropping annual tillage methods, show different modulating effects on soil properties. Therefore, additional studies involving more soil types and longer agricultural periods are needed to further improve the tillage system and ultimately determine the optimal soil tillage mode for the wheat-maize double cropping system in the Haihe Plain, China.

\section{Conclusions}

In the wheat-maize double cropping system in the Haihe Plain of China, both single- and two-season subsoiling effectively reduced soil bulk density and water/fertilizer usage in the middle-deep soil layer and increased soil porosity, soil temperature, respiration rate, and the activities of specific soil enzymes. Therefore, the synergistic interactions between water, fertilizer, and heat in soil ensured the sustainable productivity of soil and achieved higher water/fertilizer use efficiency, leading to a higher annual yield of wheat and maize.

\section{Acknowledgements}

The authors acknowledge that this work was financially supported by the Key R\&D projects in Hebei Province (Grant No. 20326407D), National Key Research and Development Project (Grant No. 2017YFD0300906), National Science and Technology Support Project (Grant No. 2012BAD04B06).

\section{[References]}

[1] Huynh H T, Hufnagela J, Wurbs A, Bellingrath-Kimura S D. Influences of soil tillage, irrigation and crop rotation on maize biomass yield in a 9-year field study in Müncheberg, Germany. Field Crop Res, 2019; 241: 107565. doi: 10.1016/j.fcr.2019.107565.

[2] Kouselou M, Hashem S, Eskandari I, McKenzie B M, Karimi E, Rezaei A, et al. Quantifying soil displacement and tillage erosion rate by different tillage systems in dryland northwestern Iran. Soil Use and Manage, 2018; 34(1): 48-59.

[3] Prosser J I, Bohannan B J M, Curtis T P, Ellis R J, Firestone M K, Freckleton R P, et al. The role of ecological theory in microbial ecology.
Nature Reviews Microbiology, 2007; 5: 384-392.

[4] Kasper M, Buchan G D, Mentler A, Blum W E H. Influence of soil tillage systems on aggregate stability and the distribution of $\mathrm{C}$ and $\mathrm{N}$ in different aggregate fractions. Soil Till Res, 2009; 105: 192-199.

[5] Hou X Q, Jia Z K, Han Q F, Sun H X, Wang W, Nie J F, et al. Effects of different rotational tillage patterns on soil structure, infiltration and water storage characteristics in dryland. Transactions of the CSAE, 2012; 28: 85-94. (in Chinese)

[6] Zhou H, Lyu Y Z, Yang Z C, Li B G. Influence of conservation tillage on soil aggregates features in north China Plain. Agricultural Sciences in China, 2007; 6: 1099-1106.

[7] Alvarez R, Steinbach H S. A review of the effects of tillage systems on some soil physical properties, water content, nitrate availability and crops yield in the Argentine Pampas. Soil \& Tillage Research, 2009; 104: 1-15.

[8] Tan C J, Cao X, Yuan S A, Wang W Y, Feng Y Z, Qiao B. Effects of long-term conservation tillage on soil nutrients in sloping fields in regions characterized by water and wind erosion. Sci Rep-UK, 2015; 5: 17592. doi: 10.1038/srep17592.

[9] Zhang X F, Xin X L, Yang W L, Ding S J, Ren G C, Li M R, et al. Soil respiration and net carbon flux response to long-term reduced/no-tillage with and without residues in a wheat-maize cropping system. Soil Till Res, 2021; 214: 105182. doi: 10.1016/j.still.2021.105182.

[10] Ussiri D A N, Lal R, Jarecki K. Nitrous oxide and methane emissions from long term tillage under a continuous corn cropping system in Ohio. Soil Till Res, 2009; 104(2): 247-255.

[11] Zhang Z S, Chen J, Liu TQ, Cao C G, Shen M X, Zhang X, et al. Integrative effects of soil tillage and straw management on crop yields and greenhouse gas emissions in a rice-wheat cropping system. Eur J Agron, 2015; 63: 47-54

[12] $\mathrm{Hu} \mathrm{N} \mathrm{J,} \mathrm{Chen} \mathrm{Q,} \mathrm{Zhu} \mathrm{L} \mathrm{Q.} \mathrm{The} \mathrm{responses} \mathrm{of} \mathrm{soil} \mathrm{N}_{2} \mathrm{O}$ emissions to residue returning system: a meta-analysis. Sustainability, 2019; 11(3): $1-17$.

[13] Guan D H, Mahdi M A, Zhang Y S, Duan L S, Tan W M, Zhang M C, et al. Tillage practices affect biomass and grain yield through regulating root growth, root-bleeding sap and nutrients uptake in summer maize. Field Crop Res, 2014; 157: 89-97.

[14] Moreira W H. Stageal changes in soil physical properties under long-term no-tillage. Soil Till Res, 2016; 160: 53-64.

[15] Zhang Y J, Wang R, Wang H, Wang S L, Li J. Soil water use and crop yield increase under different long-term fertilization practices incorporated with two-year tillage rotations. Agr Water Manage, 2019; 221: 362-370.

[16] Xu D, Mermoud A J. Topsoil properties as affected by tillage practices in North China. Soil Till Res, 2001; 60(1): 11-19.

[17] Kuang N K, Tan D C, Li H J, Gou Q S, Li Q Q, Han H F. Effects of subsoiling before winter wheat on water consumption characteristics and yield of summer maize on the North China Plain. Agric Water Manage, 2020; 227: 1-6.

[18] Li B, Chen Y, Chen J. Comparison of two subsoiler designs using the discrete element method (DEM). Trans. ASABE, 2018; 61(5): 1529-1537.

[19] Yin B Z, Hu Z H, Wang Y D, Zhao J, Pan Z H, Zhen W C. Effects of optimized subsoiling tillage on field water conservation and summer maize (Zea mays L.) yield in the North China Plain. Agr Water Manage, 2021; 247: 106732. doi: 10.1016/j.agwat.2020.106732

[20] Camp C R, Sadler E J J. Irrigation, deep tillage, and nitrogen management for a corn-soybean rotation. Transactions of the ASABE, 2002; 45(3): 601-608.

[21] Wang H H, Guo Q C, Li X, Li X, Yu Z X, Li X Y, et al. Effects of long-term no-tillage with different straw mulching frequencies on soil microbial community and the abundances of two soil-borne pathogens. Appl Soil Ecol, 2020; 148: 103488. doi: 10.1016/j.apsoil.2019.103488.

[22] Hou X Q, Jia Z K, Han Q F, Li R, Wang W, Li Y P. Effects of rotational tillage practices on soil water characteristics and crop yields in semi-arid areas of north-west China. Soil Res, 2011; 49: 625-632.

[23] López-Fando C, Dorado J, Pardo M T. Effects of zone-tillage in rotation with no-tillage on soil properties and crop yields in a semi-arid soil from central Spain. Soil Till Res, 2007; 95: 266-276.

[24] Hou X Q, Li R, Jia Z K, Han Q F, Wang W, Yang B P. Effects of rotational tillage practices on soil properties, winter wheat yields and water-use efficiency in semi-arid areas of north-west China. Field Crop Res, 2012; 129: 7-13.

[25] Zhao X, Yang H, Yang Z F, Chen B, Qin Y. Applying the input-output method to account for water footprint and virtual water trade in the Haihe River Basin in China. Environmental Science \& Technology, 2010; 44: 
9150-9156.

[26] Lu J S, Geng C M, Cui X L, Li M Y, Chen S H, Hu T T. Response of drip fertigated wheat-maize rotation system on grain yield, water productivity and economic benefits using different water and nitrogen amounts. Agr Water Manage, 2021; 258: 107220. doi: 10.1016/ j.agwat.2021.107220

[27] Cavalieri K M V, da Silva A P, Tormena C A, Leão T P, Dexter A R, Håkansson I. Long-term effects of no-tillage on dynamic soil physical properties in a Rhodic Ferrasol in Paraná, Brazil. Soil Till Res., 2009; 103: $158-164$.

[28] Conyers M, van der Rijt V, Oates A, Poile G, Kirkegaard J, Kirkby C. The strategic use of minimum tillage within conservation agriculture in southern New South Wales, Australia. Soil Till Res, 2019; 193: 17-26.

[29] Li Z, Wang L, Liu S, Zhao B, Qian X, Li Q, et al. Annual high efficiency utilization of water and fertilizer of a wheat-maize double cropping system. Sci Agric Sin, 2020; 53(21): 4333-4341.

[30] Kan Z, Liu Q, He C, Jing Z, Virk A L, Qi J, et al. Responses of grain yield and water use efficiency of winter wheat to tillage in the North China Plain. Field Crop Res, 2020; 249: 107760. doi: 10.1016/j.fcr.2020.107760.

[31] Lipiec J, Hatano R. Quantification of compaction effects on soil physical properties and crop growth. Geoderma, 2003; 116(1-2): 107-136.

[32] Tracy S R, Black C R, Roberts J A, Mooney S J. Soil compaction: a review of past and present techniques for investigating effects on root growth. J Sci Food Agric, 2011; 91(9): 1528-1537.

[33] Andersen M N, Munkholm L J, Nielsen A L. Soil compaction limits root development, radiation-use efficiency and yield of three winter wheat (Triticum aestivum L.) cultivars. Acta Agric. Scand. Sect. B-Soil Plant Sci., 2013; 63(5): 409-419.

[34] Ferraro D O, Ghersac C M. Quantifying the crop management influence on arable soil condition in the Inland Pampa (Argentina). Geoderma, 2007; 141(1-2): 43-52.

[35] Aimrun W, Amin M S M, Eltaib S M. Effective porosity of paddy soils as an estimation of its saturated hydraulic conductivity. Geoderma, 2004; 121(3-4): 197-203.

[36] Aikins S, Afuakwa J. Effect of four different tillage practices on soil physical properties under cowpea. Agricultural and Biological Journal of North America, 2012; 3(1): 17-24.

[37] Wang Z H, Deng X P, Liu L S, Zhao Z P. Effects of drought on photosynthate supplying capability of flag leaf in different winter wheats. Journal of Northwest Sci-Tech University of Agriculture and Forestry, 2009; 5: 81-88

[38] Zhang Z Y, Zhang Y L, Huang Y, Zou H T, Zhang Y L. Effects of plastic-film mulching and subsoiling measures on growth and yield of maize. Chinese Journal of Soil Science, 2009; 40: 1156-1159. (in Chinese)

[39] Anderson J M, Ingram J S I. Ion exchange resin bag method of assessing forest soil nitrogen availability. Soil Science Society of America Journal, 1989; 47: 1050-1052.

[40] Guan S Y. Soil Enzymes and Its Methodology. Beijing: Agricultural Press, 1986; pp.274-340. (in Chinese)

[41] Ruehlmann J. Soil particle density as affected by soil texture and soil organic matter: 1. Partitioning of SOM in conceptional fractions and derivation of a variable SOC to SOM conversion factor. Geoderma, 2020; 375: 114542. doi: 10.1016/j.geoderma.2020.114542.

[42] Wei L, Sheng H, Pan B, Liu G H, Song D S. Subsoil microbial quotient derived from different parent materials in east Hunan province. Soil and Crops, 2016; 5: 255-260.

[43] Wang M, Liu X T, Zang J T, Li X J, Wang G D, Li X Y, et al. Diurnal and seasonal dynamics of soil respiration at temperate leymus chinensis meadow steppes in western Songnen plain, China. Chinese Geogr Sci, 2014; 24: 287-296.

[44] Chen J K, Zhang Y, Chen J S, Chen F, Zhang H L. Characteristics of soil temperature and its response to air temperature under different tillage systems-characteristics of soil temperature and thermal properties. Scientia Agricultura Sinica, 2009; 42: 2747-2753.

[45] Ramon J, Agnès H. Effects of tillage systems in dryland farming on near-surface water content during the late winter period. Soil Till Res,
2005; 82: 173-183.

[46] Zhang Y J, Wang R, Wang S L, Wang H, Xu Z G, Jia G C, et al. Effects of different sub-soiling frequencies incorporated into no-tillage systems on soil properties and crop yield in dryland wheat-maize rotation system. Field Crop Res, 2017; 209: 151-158.

[47] Wang Y, Chen S, Zhang D X, Yang L, Cui T, Jing H, et al. Effects of subsoiling depth, period interval and combined tillage practice on soil properties and yield in the Huang-Huai-Hai Plain, China. J Integr Agric, 2020; 19(6): 1596-1608.

[48] Bai W X, Li J, Wang Y L, Wang L. Effects of different methods on soil water and crop yield of winter wheat-spring maize rotation region Weibei highland. Acta Biochimica et Biophysica Sinica, 2014; 47: 880-894. (in Chinese)

[49] Zhang Y J, Wang S L, Wang H, Ning F, Zhang Y H, Dong Z Y, et al. The effects of rotating conservation tillage with conventional tillage on soil properties and grain yields in winter wheat-spring maize rotations. Agr Forest Meteorol, 2018; 263: 107-117.

[50] Whitmore A P, Whalley W R, Bird N R A, Watts C W, Gregory A S. Estimating soil strength in the rooting zone of wheat. Plant Soil, 2011; 339: 363-375.

[51] Kouselou M, Hashem, S, Eskandari I, McKenzie B M, Karimi E, Rezaei A, et al. Quantifying soil displacement and tillage erosion rate by different tillage systems in dryland northwestern Iran. Soil Use and Manage, 2018; 34(1): 48-59.

[52] Ding S J, Xiong S P, Ma X M, Zhang J J, Wang X C, Wu Y X, et al Effects of tillage and nitrogen application rate on soil nitrogen transformation and yield in a winter wheat/summer maize multiple cropping system. Chinese Journal of Applied Ecology, 2017; 28: 142-150. (in Chinese)

[53] Zhang L, Wang J, Guo Z, Fu G Z, Zhao Y G. Rotary tillage in rotation with plowing tillage improves soil properties and crop yield in a wheat-maize cropping system. PLoS One, 2018; 13: e0198193. doi: 10.1371/journal.pone.0198193.

[54] Chen J K, Zhang Y, Chen J S, Chen F, Zhang H L. Characteristics of soil temperature and its response to air temperature under different tillage systems-characteristics of soil temperature and thermal properties. Sci Agric Sin, 2009; 42: 2747-2753.

[55] Sang X G, Wang D, Lin X. Effects of tillage practices on water consumption characteristics and grain yield of winter wheat under different soil moisture conditions. Soil Till Res, 2016; 163: 185-194.

[56] Yin B Z, Zhen W C, Ma Y H. Effects of subsoiling-seeding on soil water, temperature and microbial characteristics of summer maize field. Chinese Journal of Eco-Agriculture, 2015; 23: 285-293. (in Chinese)

[57] Mohanty M, Bandyopadhyay K K, Painuli D K, Ghosh P K, Misra A K, Hati K M. Water transmission characteristics of a Vertisol and water use efficiency of rainfed soybean (Glycine max (L.) Merr.) under subsoiling and manuring. Soil Till Res, 2007; 93: 420-428.

[58] Zhang D C, Cai D X, Dai K, Feng Z H, Zhang X M, Wang X B. Soil respiration and its responses to soil moisture and temperature under different tillage systems in dryland maize fields. Acta Ecol Sin, 2013; 33: 1916-1925. (in Chinese)

[59] Kabiri V, Raiesi F, Ghazavi M A. Tillage effects on soil microbial biomass, SOM mineralization and enzyme activity in a semi-arid Calcixerepts. Agriculture Ecosystems \& Environment, 2016; 232: 73-84.

[60] Stone M M, DeForest J L, Plante A F. Changes in extracellular enzyme activity and microbial community structure with soil depth at the Luquillo Critical Zone Observatory. Soil Biol Biochem, 2014; 75: 237-247.

[61] Huang B L, Wang M X, Jin X J, Hu G H, Zhang Y X. Effects of different tillage treatments on soil microorganisms, enzyme activities and nutrients. Crops, 2019; 35: 167-176. (in Chinese)

[62] Shahidi B M, Dyck M, Malhi S S. Carbon dioxide emissions from tillage of two long-term no-till Canadian prairie soils. Soil Till Res, 2014; 144 : $72-82$.

[63] Balota E L, Calegari A, Nakatani A S, Coyne M S. Benefits of winter cover crops and no-tillage for microbial parameters in a Brazilian oxisol: a long-term study. Agriculture Ecosystems \& Environment, 2014; 197: 31-40. 